\title{
Health Services in Turkey with the View of Syrian Asylum Seekers
}

\author{
Yunus Emre ÖZTÜRK ${ }^{1}$, Hilal AKMAN DÖMBEKCÍ ${ }^{2}$
}

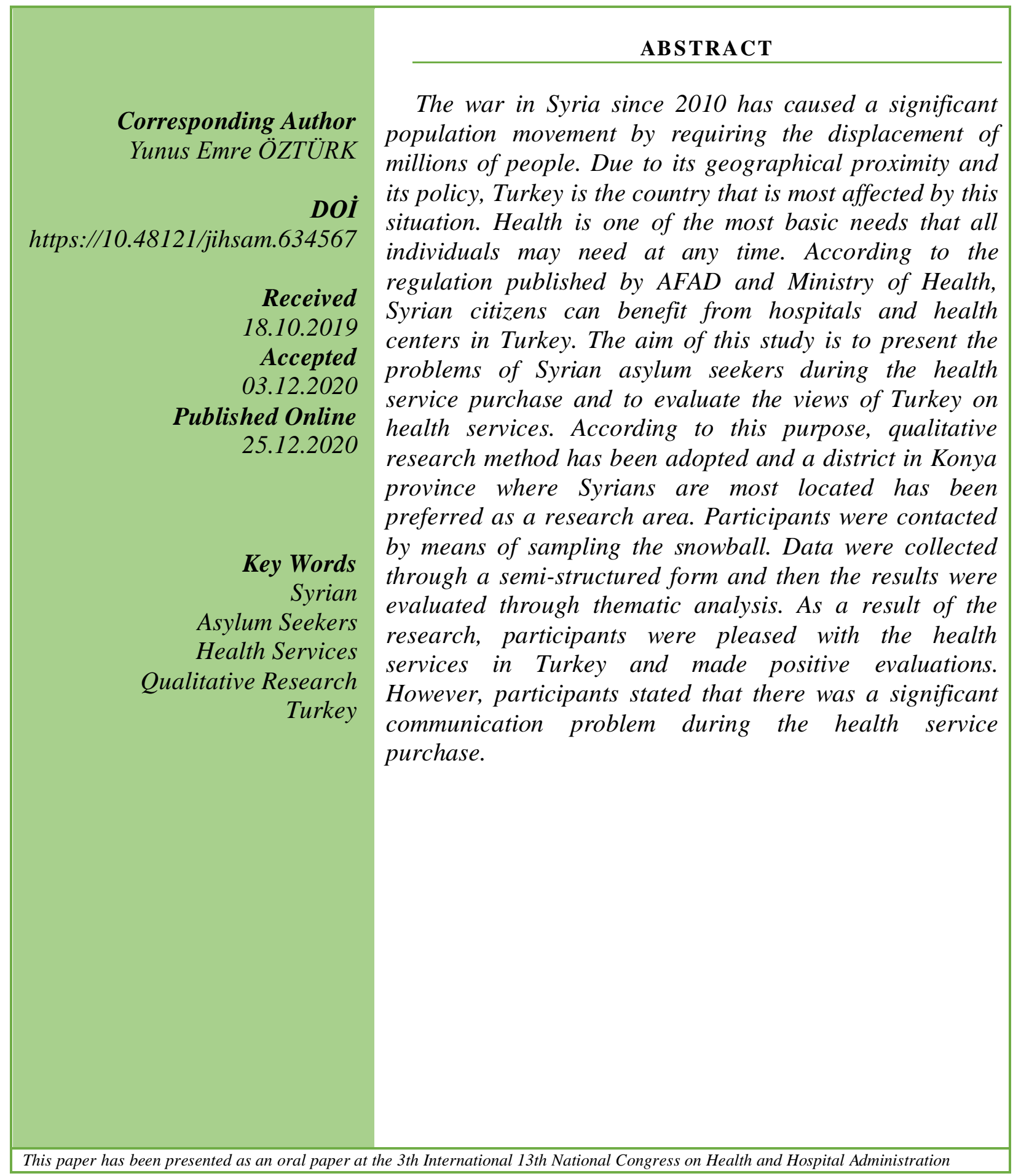

\footnotetext{
${ }^{1}$ Selcuk University/Healty Care Management/Turkey/ yunuseoztuk@gmail.https://orcid.org/0000-0002-6178-6129

${ }^{2}$ Selcuk University/Healty Care Management/Turkey/akmanhilal@hotmail.com https://orcid.org/0000-0003-0089-860X
} 


\section{INTRODUCTION}

It is seen that, throughout history, people have been changing places to facilitate their lives. The process of displacement involves not only a spatial change, but also a cultural change (Kolukırık 2009). The war climate in Syria since 2010 has caused a significant population movement by necessitating the displacement of millions of people. Due to its geographical proximity and its policy, Turkey is the country that is most affected by this situation. Syrian refugees are in Turkey as well as to influence both political and social structure, it covers a wide place in the agenda of the international community (Pandir and ark 2015).

Asylum seekers face many problems in the new country, such as education, language, health, social relations and economic problems (Elmac1 2014). Health is the most important of these issues. The health status of asylum-seekers varies depending on their previous environment, social relations, the safety of their new environment, whether they know language and access to social assistance (SASAM 2016). Turkey, which is hosting 3.5 million Syrians, is the country that has the most Syrian asylum seekers (Ministry of Interior 2018). Health problems associated with such a large population of asylum seekers can adversely affect both asylum seekers and the local population. The aim of this study is to reveal the problems faced by Syrian refugees during the health service procurement and to evaluate their point of view on health services.

\section{Asylum Seeker, Refugee and Temporary Protection Concepts}

The concept of asylum-seeker refers to "a foreigner who is outside the country of his nationality because he is afraid of being prosecuted because of his race, religion, nationality, membership in a particular social group or because of his political beliefs and cannot benefit from the protection of the country of his nationality" (EGM 2018). In related sources, it is observed that the concept of asylum-seeker refers to the situation before refugee status. So that asylum seekers are made up of people who are in the position of a candidate refugee.

The refugees are "foreigners who are outside the country of their nationality and cannot benefit from the patronage of the country of their nationality because of their race, religion, nationality, membership in a particular social group or because of their political beliefs" (EGM 2018). Due to the geographical limitation in the definition of refugees, it is not possible for peoples from outside European countries to be described as refugees. According to this, Syrians may only be asylum seekers (Başak 2011). On the other hand, is given "temporary protection" to the Syrians living in Turkey, according to the 91st article of the Law on Foreigners and International Protection, since 28 April 2011. (Gülay
2016). The concept of asylum seekers is used for the people who came from Syria to Turkey due to war and persecution (İncili and Akdemir 2016)

Temporary protection is an improved as a practical solution to the people who reach the borders of the country in mass, in order to find emergency solutions without delay within the context of the obligation of states not to send them back (Ministry of Interior 2018). With the implementation of temporary protection, the Syrians living in Turkey are provided with unlimited stay permits and sufficient assistance to provide solutions to urgent needs (Hassoy 2016). The legal expression of Syrians living in Turkey is very important in terms of access to health services and some social services.

\section{Health Problems of Syrian Asylum Seekers}

The basic needs of Syrian asylum seekers in Turkey as it is anywhere; safety, nutrition, shelter, health, education, protection from violence and abuse (Hassoy 2016). Each of these issues is important, but only health issues are addressed here. So much so that asylum-seekers both have serious health problems and cause health problems in the societies they migrate to (Çiçek Korkmaz 2014). When the asylum seekers are located in a collective area, they can cause the region to change or increase its health problems (SASAM 2016). The living conditions and health problems of asylum seekers are very risky for communicable diseases and the spread of these diseases. It is an important public health obligation to control the health status of asylum-seekers and to remedy their health needs (TTB 2014).

Some of the challenges of asylum seekers to benefit from health services can be listed as follows;

- Health services are supposed to be paid,

- Difficulties in access to service (transportation fee, distance, etc.)

- Failure to adapt to health services and lack of functioning,

- Differences of the language and culture

- Lack of identity documents or not specifying the identity clearly (çiçek korkmaz 2015).

\section{Health Services For Syrian Asylum Seekers In Turkey}

The use of health services of asylum-seekers in Turkey has been determined by the "execution of health services for foreigners under Temporary Protection" published by Amnesty as of 2015 and "principles on health services for those who are under temporary protection" put into effect by the Ministry of Health. According to this directive, persons under temporary protection (Ministry of Health 2014): 
a) Health centers established in temporary accommodation centers,

b) Health service providers belonging to the ministry and affiliated organizations,

c) University health practice and research centers,

d) Private hospitals,

e) They can benefit from health services provided voluntarily by foundations or associations.
Syrian nationals can benefit from hospitals and health centers in Turkey as per the regulations published by the AFAD and Ministry of Health. The price of this service is billed to the governorship of the province where the institution is located (SASAM 2016). With these opportunities provided by the state, the health of both asylum seekers and the society is tried to be protected and improved.

\section{METHOD}

Qualitative research method was used in this study. Qualitative research methods are considered appropriate when researching participant's perspectives or daily behaviors (Büyüköztürk et al., 2014). Qualitative research is carried out with fewer participants unlike the quantitative method (Y1ldirım and Şimşek 2011). Başkale (2016) stated that it is sufficient to conduct interviews with about 30 people in qualitative research, which collected data through in-depth interviews (Başkale 2016). This study was carried out with 35 participants due to both qualitative characteristics and time and economic constraints. The criteria for participating in the study is to come to Turkey as an asylum seeker from Syria at least a year ago because of the war and become an adult (18-65 years old). Another criterion is to have received health care in Turkey at least once, for one's own or one's relatives. Participants are also required to volunteer to participate in the study. The criteria for living in Turkey for at least a year has been deemed necessary in order to have enough experience to evaluate the health services of Turkey. The study was conducted in Konya province. Konya Meram Gazi Alemşah district, where Syrians live extensively, was preferred for the collection of research data. The research data were collected through snowball sampling. Snowball samples are very popular, especially for researchers who work on sensitive subjects and hard to reach audiences (Berg and Lune 2015). A semi-structured interview technique was used for gather data. Attention has been paid to a brief and clear understanding of the research questions. The translator support was received during the interview. The interview questions were created under the supervision of researchers and an expert professor in the field. A preliminary interview was held to check the comprehensibility and fitness of the questions. Afterwards, necessary corrections were made to the questions and data began to be collected. The Syrian individuals who were interviewed were asked the following questions about Turkey's health services;

- How long have you been in Turkey?

- Have you benefited from health services in Turkey?

- Where did you apply for health services?

- Has your health problem been resolved by receiving health care? Can you evaluate the process?

- Have you had any communication problems while receiving health care? Can you explain that?

- Can you evaluate the approach of health personnel to you?

- Can you evaluate Turkey's health services?

In the analysis of the data, a code $(\mathrm{K} 1, \mathrm{~K} 2 \ldots)$ was given for each participant. Then, the data were classified according to the similarities of the expressions. Classified items are divided into main themes. Then, sub-themes were created by classifying the data in each main theme according to their similarities. No analysis program was used for the analysis. To ensure reliability, the data set was presented to 3 independent academics and asked to analyze. Then, when the results were compared, they were found to be similar. The type of analysis used in the study is thematic analysis. Thematic analysis facilitates the summarization, explanation, interpretation and transfer of research data to the reader by classifying them within certain categories (Yıldırım and Şimşek 2011). Tables were used in the presentation of the data after the analysis. The data are expressed by frequency with theme and participant codes. According to Lincoln and Guba (1985), quotations are very important to demonstrate the objectivity of the study, and the findings should include the participants' own statements rather than the researcher's views. In this study, original quotations from participant statements are included.

\section{RESULTS}

In this section, the data is presented. Firstly Table 1 contains information about how long the participants have been in Turkey and whether they should receive health care. Table 2 contains information about the satisfaction level of the participants about the health services that they receive. Table 3 details about the communication problems, Table 4 with medical staff relations and finally Table 5 contains information about general evaluation of health services in Turkey. 
Table 1. Information about the participants

\begin{tabular}{llrr}
\hline Variables & & f & \% \\
\hline \multirow{2}{*}{ The duration of participants in Turkey } & 1-2 years & 13 & 37,14 \\
& 3-4 years & 22 & 62,86 \\
\hline \multirow{2}{*}{ Benefit from health services in Turkey } & Yes, I took & 20 & 57,14 \\
& My relatives took & 15 & 42,86 \\
\hline \multirow{2}{*}{ The stage applied for healthcare } & 1st level & 4 & 11,43 \\
& 2nd level & 19 & 54,29 \\
& 3rd level & 12 & 34,28 \\
\hline
\end{tabular}

$62 \%$ of participants, as shown in Table 1 , has been living in Turkey for 3-4 years. 57\% of the participants received health services themselves in Turkey and the rest applied to the health institution for a close relative. $54 \%$ of the participants applied to the second level, $34 \%$ to the third level and $11 \%$ to the primary health care institutions. This information was not included in the study because demographic data such as gender and occupation were not evaluated.

Table 2. Evaluation of health care utilization process

\begin{tabular}{llllr}
\hline Themes & $\mathbf{N}$ & Sub Themes & Participant & f \\
\hline \multirow{2}{*}{$\begin{array}{l}\text { Satisfaction of } \\
\text { treatment }\end{array}$} & 1 & Depends on healing & K2, K5, K6, K7, K9, K10, K11, K12, K13, K14, K15, & 21 \\
& 2 & Satisfaction & K16, K18, K19, K22, K28, K3, K31, K32, K33, K34 & 5 \\
\hline \multirow{2}{*}{$\begin{array}{l}\text { Dissatisfaction } \\
\text { with treatment }\end{array}$} & 1 & Ineffectiveness of drugs & K1, K20, K21 & Inadequacy of doctors \\
& 3 & K4, K24, K29 & 3 \\
& Length of the process & K3, K8, K35 & 3 \\
\hline
\end{tabular}

Table 2 shows the status of the participants after the use of health care services. The data in this table are divided into two main themes as satisfaction and dissatisfaction with treatment. The theme of satisfaction, satisfaction as a result of improvement and general satisfaction is divided into two sub-themes; the theme of dissatisfaction is divided into three subthemes: the inefficiency of drugs, the inadequacy of doctors and the length of the process. It is seen that the majority of the participants are satisfied with the improvement result. The statements of some of the participants giving information about their status after use of health services are as follows; "...I was satisfied with the treatment (K16). "...my mother's heart condition is immediately cured, now better (K14)." "My treatment is going on, but I'm better now, I'm glad (K17)". "I could not get results from the treatment, the drugs did not show the effect (K20)".

Table 3. Communication problems during the use of health care

\begin{tabular}{lllll}
\hline Themes & N & Sub Themes & Participant & f \\
\hline & & & K2, K4, K5, K6, K7, K11, K12, K13, & \\
$\begin{array}{l}\text { Situations of } \\
\text { communication } \\
\text { problem }\end{array}$ & 1 & Foreign language & K15, K17, K18, K19, K22, K24, K28, & 21 \\
& 2 & Lack of interpreter & K29, K30, K31, K33, K34, K35 & \\
& 3 & Absence of translator & K2, K21, K23, K25, K26, K27, K33, K35 & 4 \\
\hline $\begin{array}{l}\text { Situations of without } \\
\text { communication } \\
\text { problems }\end{array}$ & 4 & Patient density & K3, K33 & 2 \\
\hline
\end{tabular}

In Table 3, the communication problems of the participants are presented as thematically. Communication problems are divided into sub-themes such as foreign language, lack of interpreter, absence of translator and patient density. The majority of the participants stated that they had a communication problem due to the language 
difference. Situations that do not have a communication problem are discussed in two sub-themes: to know Turkish and translator assistance. Statements of some of the participants who reported their views on communication during the health service procurement are as follows; "....we had a lack of communication, the number of patients is too high, so the interpreter is insufficient (K3)". "We had difficulties because we didn't know Turkish, the number of helpers in this regard was insufficient (K12)". "Communication is distressed, the doctor does not understand our language and therefore cannot apply effective treatment (K24)". "We had a lot of trouble because we didn't know the language, the number of patients was too much, so more translators were needed (K33)". "There were staff who knew Arabic, so we didn't have any problems (K16)" . "I had no problems, because I know Turkish (K20)" .

Table 4. The approach of health personnel to asylum seekers.

\begin{tabular}{|c|c|c|c|c|}
\hline Themes & $\mathbf{N}$ & Sub Themes & Participant & f \\
\hline \multirow{3}{*}{ Positive } & 1 & Very good & $\begin{array}{l}\text { K1, K3, K6, K8, K9, K13, K15, K16, K17, K18, K20, K21, K23, } \\
\text { K28, K30, K32, K35 }\end{array}$ & 17 \\
\hline & 2 & Good & $\mathrm{K} 10, \mathrm{~K} 19, \mathrm{~K} 29, \mathrm{~K} 33$ & 4 \\
\hline & 3 & Friendly & $\mathrm{K} 4, \mathrm{~K} 5, \mathrm{~K} 7, \mathrm{~K} 11, \mathrm{~K} 14, \mathrm{~K} 22, \mathrm{~K} 24$ & 7 \\
\hline \multirow{3}{*}{ Negative } & 1 & Gender discrimination & K25, K27 & 2 \\
\hline & 2 & Racial segregation & $\mathrm{K} 12, \mathrm{~K} 26, \mathrm{~K} 34$ & 3 \\
\hline & 3 & Foreign language & $\mathrm{K} 2, \mathrm{~K} 31$ & 2 \\
\hline
\end{tabular}

In Table 4, the participants expressed views on the health personnel of Turkey. It is seen that the majority of the participants think positively with very good sub-theme. Negative perspectives are divided into three categories: gender discrimination, racial segregation and language difference. Some participant statements on the approach of health personnel to Syrian patients are as follows; "I was pleased, their approach to us was very good (K6)". "They behaved very well, we never felt like strangers (K5)".
"They were very good, there was no problem, they treated us well (K18)". "...they were sincerely and friendly (K24)". "We've had a lot of trouble, some medical staff treated us badly...(K26)". "...some have behaved very badly, health personnel treat Syrian women differently than Syrian men (K27)". Nurses are treating asylum seekers badly, they want an interpreter, they don't have dialogue and they have bad behavior (K2)".

Table 5. Opinions of participants on Turkey's health services

\begin{tabular}{lllr}
\hline No & Themes & Participant & f \\
\hline 1 & Advanced technological equipment & K1, K2, K6, K13, K15, K21, K24, K34, K35 & 9 \\
& Inexperience of physicians & K8, K9, K10, K13, K15, K16, K18, K20, K23, K24, & 14 \\
3 & Inadequate service & K30, K33, K34, K35 & 6 \\
4 & Advanced health care & K24, K25, K26, K29, K30, K33 & \\
\hline
\end{tabular}

Table 5 shows that the participants' views on Turkey's health care services. These thoughts are divided into four themes: advanced technological equipment, inexperience of physicians, inadequate service and advanced health care. The majority of the participants think that Turkey has an improved health service. In addition, there are also participants who think that physicians are inexperienced and that health services are insufficient. Some participant statements that support the table are as follows; "We were very pleased, health care is fine, technology is more advanced in Turkey (K1)". "Everything is very good related to the health system in Turkey... (K4)". "Turkey's technology is more advanced than Syria, but doctors in Syria were better than doctors in Turkey 
(K13)". "There is no problem with the health care system, only assistant doctors are inexperienced ... (K23)." "In Turkey, doctors apply treatment according to medical device results... (K24)". "We couldn't get enough service in the here (K26)". "Health service in Turkey is very good and developed (K28)". "The doctors were better in Syria (K30)".

\section{CONCLUSION AND EVALUATION}

First of all, more than $60 \%$ of the participants surveyed in this research have been living in Turkey for 3-4 years. In this time period, they are considered to have access to the ability to evaluate health services. All of the participants received health care by applying to health institutions in Turkey for themselves or their relatives. Participants mostly expressed satisfaction with health care as a result of getting rid of their illness. However, the majority of the participants experienced a communication problem when they received health care service. There was no communication problems related to the language difference when the participants knew Turkish and had a sufficient number of qualified translators.

The participants are a positive evaluations by expressing that Turkey has an advanced health service. The participants who have negative thoughts stated that health personnel working in Turkey discriminated against Syrians. There are also participants who express that physicians working in Turkey are inexperienced and very dependent on technology.

In other studies on Syrian asylum seekers, it was found that there was difficulty in communication. According to a study conducted by Kalkan et al. (2015),
$26.3 \%$ of Syrian asylum seekers have language problems among the reasons for not applying for health services. According to a survey by Kara and Akgün (2015) on Syrian asylum seekers, the most important reason for not being able to reach health services is the language problem by $42 \%$. According to Kara and Akgün (2015), 36\% of the respondents stated that they did not receive adequate health care and/or were dissatisfied. Syrian asylum seekers and Health Services report published by Turkish Medical Association states that because of the language problem, asylum seekers have significant problems in accessing public services, primarily health services, education, work and social life (TTB 2014). These problems related to language and communication can be reduced by employing more interpreters in health services.

This research was carried out in Konya to assess Syrian asylum seekers ' views on health services in Turkey. However, there are many issues that need to be investigated for asylum seekers. First of all, after the determination of issues such as social adaptation, education, working life, economic difficulties, a study can be done on the solution of these problems. 


\section{RESOURCES}

AFAD (2015). Geçici Koruma altındaki Yabancılara İlişkin Sağlık Hizmetlerinin Yürütülmesi. Afet ve Acil Durum Yönetimi Başkanlığı,

https://www.afad.gov.tr/upload/Node/2311/files/2015_8_Gecici_K oruma_altindaki_Yabancilara_Iliskin_Saglik_Hizmetlerinin_Yurut ulmesi.pdf, Erișim Tar: 02.10.2018.

Başak, C. (2011). Mülteciler, sığınmacılar ve yasa dışı öçmenler. Ankara: İçişleri Bakanlığı Yayını.

Başkale, H. (2016). Nitel Araştırmalarda Geçerlik, Güvenirlik ve Örneklem Büyüklüğünün Belirlenmesi, Dokuz Eylül Üniversitesi Hemşirelik Fakültesi Elektronik Dergisi, 9(1): 23-28.

Berg, B.L. and Lune, H. (2015). Sosyal bilimlerde nitel araştırma yöntemleri. (Çev. Hasan Aydın), Konya: Eğitim Yayınevi.

Büyüköztürk, Ş. Kılıç, Çakmak, E. Akgün, ÖE. Karadeniz, Ş. Demirel, F. (2014). Bilimsel araştırma yöntemleri, Ankara: Pegem Akademi.

Çiçek, Korkmaz, A. (2014). Sığınmacıların Sağlık ve Hemşirelik Hizmetlerine Yarattığı Sorunlar, Sağlık ve Hemşirelik Yönetimi Dergisi, 1(1):37-42.

Ciçek, Korkmaz, A. (2015). Mültecilerin / Sı ğınmacıların sağlık sorunları ve hemşirelik yaklaşımı. İn: 18. Ulusal Halk Sağlığı Kongresi, Konya, p. 123.

Elmacı, D. (2014). Sı ğınmacı çocukların maruz kaldığı kültürel şiddet. Ed. Büke H. Çocuk ve Şiddet: Toplumsal Şiddetin Cenderesinde Çocuklar. Cilt 1, SAMER Bilimsel Yayınlar Serisi, p. 71-78.

Gülay, M. (2016). Sağlık hakları alanındaki hukuki düzenlemeler. İn: Savaşlar, Göç ve Sağılı. Ankara: Türk Tabipleri Birliği Yayınları, p. 76-82.

Hassoy, H. (2016). Sığınmacılara ilișkin genel durum. İn: Savaşlar, Göç ve Sağlık. Ankara: Türk Tabipleri Birliği Yayınları, p. $16-19$.

İncili Ö.F., Akdemir İ.O., (2016). Yerinden edilmişliğin coğrafi analizi: kilis'te suriyeli sığınmacılar. Marmara Coğrafya Dergisi, 34: 118-33.
Kalkan, O., Gülay, M., Vatan, İ., Engindeniz, F.T., Bakıș, B., Mutlu, M. and Özbek, R. (2014). Bursa İli Osmangazi ilçesinde ikamet eden suriyeli göçmenlerin temel sağlık durumlarının değerlendirilmesi. 17. Ulusal Halk Sağlığı Kongresi Edirne, p. $457-458$.

Kara, F. and Akgün, N. (2015). Konya'ya yerleșen Suriyeli mültecilerin sağlık hizmetlerinden yararlanmalarının önündeki engeller, 18. Ulusal Halk Sağlı̆̆ı Kongresi Konya, p. 216-217.

Kolkırık, S. (2009). Mülteci ve sığınmacı olgusunun medyadaki görünümü: medya politiği üzerine bir değerlendirme, Gaziantep Üniversitesi Sosyal Bilimler Dergisi, 8(1):1-20.

Lincoln, S. Y., and Guba, E. G. (1985). Naturalistic inquiry. Thousand Oaks, CA: Sage, InElo, S., Käärï̈inen, M., Kanste, O., Pölkki, T., Utriainen, K. ve Kyngäs, H. (2014). Qualitative content analysis: a focus on trustworthiness, SAGE Open, 1-10.

Pandır, M., Efe, İ., Paksoy, A.F. (2015). Türk basınında Suriyeli sığınmacı temsili üzerine bir içerik analizi, Marmara İletişim Dergisi, 24:1-26.

SASAM (2016). Göç ve halk sağlığı, Sağlık Sen Stratejik Araştırmalar Merkezi, Analiz, 2(7): 1-26.

T.C. İçişleri Bakanlığı (2018). Göç İdaresi Genel Müdürlüğü, Göç İstatistikleri, http://www.goc.gov.tr/icerik3/gecicikoruma $363 \quad 378 \quad 4713$, Erişim Tarihi: 01.10.2018.

T.C. Sağlı Bakanlığı (2014). Geçici Koruma Altına Alınanlara Verilecek Sağlık Hizmetlerine Dair Esaslar, https://dosyasb.saglik.gov.tr/Eklenti/1376,saglik-bakanligi-gecicikoruma-yonergesi-25032015pdf.pdf?0, Erişim Tar:02.10.2018.

TTB (2014). Suriyeli Sığınmacılar ve Sağlık Hizmetleri Raporu, Türk Tabipleri Birliği Yayınları, Ankara: https://www.ttb.org.tr/kutuphane/siginmacirpr.pdf, Erişim Tar: 02.10.2018.

Yildirim, A., and Şimşek, H. (2011). Sosyal bilimlerde nitel araştırma yöntemleri. Ankara: Seçkin Yayıncılık. 